\title{
BIOMASSA MACROBRACHIUM AMAZONICUM (HELLER, 1862) À JUSANTE DA USINA DE ÁGUA VERMELHA, DIVISA ENTRE OS ESTADOS DE SÃO PAULO E MINAS GERAIS
}

\author{
Nunes, J.S. ${ }^{1,}$; Castilho, R.C.C. ${ }^{1}$; Carvalho, A.L.C. ${ }^{1}$; Rodrigues, L.R. ${ }^{1}$; Costa, J.R.P. ${ }^{1}$; \\ Gomes, M.R.R.S. ${ }^{1}$ \& Andrade, L.S. ${ }^{1}$ \\ ${ }^{1}$ Universidade Federal do Triângulo Mineiro (UFTM), Campus Iturama, Grupo de Ensino, Pesquisa e Extensão \\ em Animais Aquáticos - GEPEAA \\ *Autor correspondente: jhessynunes20@hotmail.com
}

\begin{abstract}
A determinação da biomassa de uma população permite inferir sobre o equilíbrio da espécie do ambiente, bem como sobre sua importância na cadeia trófica local. Predação, disponibilidade de alimento, teor de matéria orgânica, temperatura, concentração de oxigênio e características do substrato podem ditar tal biomassa ao longo do tempo e espaço. O objetivo desse estudo foi quantificar a biomassa de Macrobrachium amazonicum no Rio Grande, à jusante da barragem da usina hidrelétrica Água Vermelha. Para tanto, foram realizadas coletas mensais entre Outubro/2017 e Março/2018 em seis transectos do rio, os quais se distanciavam gradativamente da barragem (numerados de 1 a 6 , do mais próximo ao mais distante) e, consequentemente, diferenciavam-se quanto ao efeito antrópico causado no local. A captura dos animais foi realizada por peneiras e armadilhas do tipo covo. Os indivíduos coletados foram armazenados em recipientes de vidro e fixados em álcool $70 \%$ para avaliações biométricas. Posterior a essas avaliações, a biomassa de cada transecto/mês foi colocada em estufa de secagem a $60^{\circ} \mathrm{C}$, por $96 \mathrm{~h}$, e então pesada em balança de precisão. Uma análise de variância (ANOVA) foi utilizada na comparação espaço-temporal e o Teste T forneceu resultados sobre a comparação da biomassa entre os métodos de captura. A menor biomassa média observada ocorrida mês de Fevereiro $(8,85 \pm 7,05 \mathrm{~g})$ e a maior em Novembro $(43,63 \pm 41,95 \mathrm{~g})$, no entanto não foi verificada diferença nessa avaliação temporal. Ao fazer a comparação espacial, verificou-se que o transecto de menor biomassa foi o mais distante da barragem $(4,97 \pm$ $5,93 \mathrm{~g})$, enquanto o de maior biomassa era o segundo ponto de coleta mais próximo $(44,42 \pm 50,98 \mathrm{~g})$. A ANOVA confirmou a diferença $(p<0,05)$ e o teste de Fisher apontou que este segundo ponto diferiu significativamente dos transectos posteriores (transectos 4, 5 e 6) $(p<0,02)$. Tais resultados demonstram que a biomassa da espécie estudada é provavelmente condicionada ao fato de tais locais proibirem a presença de pescadores, o que também reduz a captura de camarões para utilização de iscas.
\end{abstract}

Palavras-chave: barragem, camarão dulcícola, Decapoda, peso seco. 